\title{
WILD LIFE PRESERVATION IN THE BRITISH WEST INDIES, BRITISH HONDURAS AND BRITISH GUIANA
}

Problems of nature preservation in British territories of central America may be clearly divided between continental countries, British Honduras and British Guiana on the one hand, and the islands on the other; although the fauna of Trinidad and Tobago has much in common with that of the South American continent. The islands of the Greater and Lesser Antilles have been separated long enough from the mainland and from each other, for them to have developed their own plants and animals. Common to continental and island countries, however, are the migratory shore birds of the western hemisphere.

\section{Tine Continental Countries}

No resident mammal or bird of British Guiana or British Honduras is known to have become extinet during the last 2,000 years. This has been due to the extensive forests and the small human populations of the past, but these factors cannot be relied upon indefinitely. The time to preserve animals and plants is before the threat to their existence has developed strongly.

Britisir GuinNa contains a great variety of interesting wild life typical of the Amazon basin. Among the abundance of mammals are the capybara, the largest existing rodent; the kinkajou; three species of anteater; the giant armadillo; the jaguar ; the Brazilian tapir ; howler, capuchin and spider monkeys; agoutis and several species of deer. Amongst a wealth of birds are the extremely interesting and primitive hoatzin; the boatbill; the rosy flamingo and the rare harpy eagle.

Mammals receive complete protection in the Kaieteur National Park, an area of only 45 square miles in the 83,000 square miles of British Guiana.

Some birds receive nominal protection under the Wild Birds Protection Ordinance, which originated in 1919 but is admittedly

\footnotetext{
Reference

"Nature Preservation in the Caribbean," by J. II. Westermann. (A paper presented at the Third General Assembly of the International Union for Conservation of Nature and Natural Resources, Caracas, September, 1052.)
} 
ineffective. The Government has not put into effect the recommendations of successive committees on wild life protection. In September, 1057, the following reply was given to a question on legislation for the protection of wild life put to the Minister for National Resources by Mr. A. G. Tasker, O.B.E., a nominated member of Council :-

"The primary concern of the Government is the vigorous economic development of the country. Consequently, measures to promote such development will be given priority over the measures for which the need has not been definitely established."

There seems little indication that the Government of British Guiana intends to preserve the indigenous wild life of the country or the migratory birds which winter there.

Britisir IIondunas. A wild life protection ordinance was enacted in 1944 and regulations made in 1945. The policy of the Forest Department includes the conservation of wild life and the protection of the flora.

\section{Tine West Indian IsLands}

Wild animals and birds in these islands are especially vulnerable because their habitat is restricted and their numbers few. Animals introduced by man have, in some cases, such as cats, monkeys and the mongoose, attacked the original fauna directly; in others, such as sheep and goats, they have destroyed its habitat. Among mammals which have become extinct, or are in danger of extermination are the Jamaican hutia, an agouti from St. Lucia, Dominica, Monserrat and St. Kitts, and the Caribbean monk scal. Among birds in the same situation are the white ibis; the roseate spoonbill; the West Indian tree duck; four species of parrots and several macaws.

Jamiaca. The Wild Life Protection Act of 1944 is an example of good protective legislation. All forest reserves are made game sanctuaries and the hutia, the Caribbean monk seal and iguanas given complete protection. All birds are completely protected except those on a schedule. Importation of alien animals is rigorously restricted. $\Lambda$ wild life protection committec advises the government on the administration of the act.

Jamaica has no indigenous carnivorous mammals and the fauna is therefore especially vulnerable to introduced carnivores. Consequently the mongoose, introduced from Asia, has wiped out a number of ground-nesting birds and other animals. Some of these, unknown elsewhere, are lost to the world. 
Interest in local natural history, until recently absent, is waking up.

Barmados. The Wild Birds (Protection) Act, 1907, protects thirteen species named in a schedule. No provision is yet made for the protection of migratory shore birds.

Trinidad and Tobago. The Wild Animals and Birds Protection Ordinance of 1933, amended in 1941, protects absolutely all species except those specified in a schedule as game or harmful species. Ten full-time game wardens were appointed in 1950. A wild life protection committee was established in 1948 to advise on wild life protection and to assist in the enforcement of the game laws. Game reserves where all mammals and birds are protected have been established. New protective legislation is being considered.

On Little Tobago there is a colony of birds of paradise, descendants of birds imported from New Guinea in 1909.

\section{Mignant Sirone Binds}

Little is done to protect migrant shore birds which winter or pass through the West Indies and the northern shores of South America. Their plight has been well described by the American naturalist Mr. Richard Pough. He shows that these birds with a rather small egg clutch, with no time for a second brood because of the short summer in their Arctic breeding places and with a hazardous ocean crossing to their winter quarters, are ill-equipped to stand the additional toll imposed by shooting.

The full protection which has for years been given to these birds in Canadr and the United States should be supported by protective legislation in the West Indies and South America, not partly nullified by uncontrolled shooting.

\section{Education}

Wherever little is done to preserve wild life there can be little love of nature. In the West Indies there is wonderful scenery and a splendid array of fauna and flora spread for all to see. More nature education in the schools seems the greatest need.

Note. In the summer of 1958 a delegation from the Commonwealth Parliamentary Association visited the West Indies. Each member was given the names of people interested in wild life preservation in the various countries and a copy of the above notes. These were issued with the approval also of the British Section of the International Committee for Bird Preservation. 